\title{
Marine Terraces as Geomorphic Evidence of Different Tectonic Regimes in Southeastern Part of The Caspian Sea in the Late Quaternary
}

Somayeh Emadodin ${ }^{1^{*}}$ and Somayeh Zahabnazouri ${ }^{2}$

${ }^{1}$ College of Geography, University of Gorgan, Golestan, Iran

${ }^{2}$ College of Geography, University of Tehran, Tehran, Iran

*Corresponding author: Somayeh Emadodin, University of Gorgan, Golestan, Iran, Tel: +98-9132994541; E-mail: emadodin1862007@yahoo.com

Received Date: September 8, 2018; Accepted Date: October 3, 2018; Published Date: October 8, 2018

Copyright: (C) 2018 Emadodin S, et al. This is an open-access article distributed under the terms of the Creative Commons Attribution License, which permits unrestricted use, distribution, and reproduction in any medium, provided the original author and source are credited.

\begin{abstract}
The comparison of geomorphologic evidences of Gorgan and Neka Rivers near their estuary point into the Caspian Sea represents different channel down cutting and depositional sequence, so that Neka River shows a deeper down cutting near the estuary point, this research is seeking the reason of the difference. As a result, the marine terraces were used as the geomorphologic indexes to show Neka River down cutting and coastal uplift assessment. Totally there were 8 marine terraces identified by studying geological maps, satellite images and outcrop investigations. 8 bivalve fossil samples were selected for carbon dating of the terraces. Afterwards the exact position and elevation of terraces were measured and their topographic cross sections were drawn up to the coast line. The carbon dating results show that tectonic forces did not act similarly in the eastern and southern parts of the Caspian Sea and the major reason for Neka River down cutting was related to Alborz mountains uplift Based on the results, it can be understood that Alborz Mountains uplifted during some 500 years causing about 1.02 meters' uplift in southern Caspian in comparison to the eastern part of it.
\end{abstract}

Keywords: Marine terraces; Geomorphology; Tectonic; Caspian sea

\section{Introduction}

The Caspian Sea level (CSL) has experienced substantial fluctuations during Quaternary [1-12]. In the Quaternary alone, sealevel cycles of five orders of magnitude were established, with a range between at least $+50 \mathrm{~m}$ during the last Glacial and $-113 \mathrm{~m}$ during the Early Holocene(Figure 1)[7,8].

Caspian Sea level fluctuations in the last 170 years especially between 1930s to 1977 show, a sea level drop by $3 \mathrm{~m}$, reaching $-29 \mathrm{~m}$ a.s.l., which is the lowest value in recent 400 years [3] whilst a rapid rise of the same order of magnitude was observed after 1977 [13]. A trend which has continued to the present as the world oceans level rose at approximately $2 \mathrm{~mm}$ /years (Figure 2)[14]. These decadal-scale variations are superimposed on a long-term down ward trend in CSL, as suggested by geological evidence derived from the dating of deltas and terraces [15]. It is generally accepted that climate-induced changes in the hydrological budget of the Caspian Sea are the main cause of CSL fluctuations $[10,13,15,16]$. Geological processes are also thought to influence the CSL. They include tectonic movements [17] and deep ground water flows between the Aral Sea and the Caspian Sea [18]. The impact of geological factors on the Caspian sea-level fluctuations were negligible for the past few thousand years [19]. In addition, anthropogenic activities such as land-use change and reservoir development affected the CSL during the 20th Century $[13,15]$.

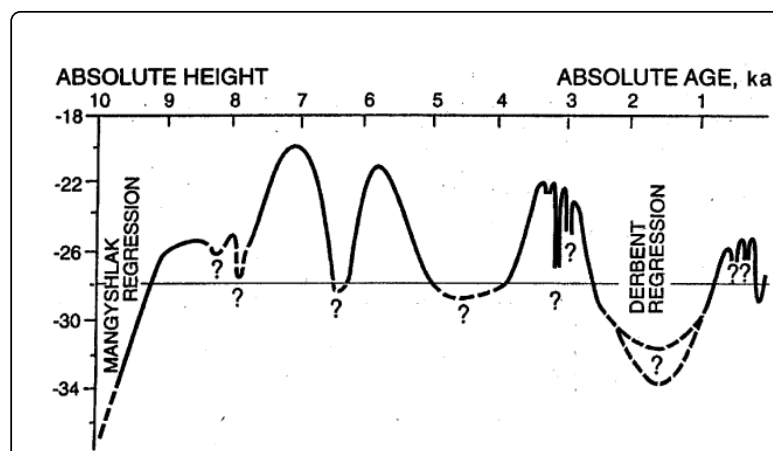

Figure 1: Fluctuation in the level of the Caspian Sea over the last 10,000 years.

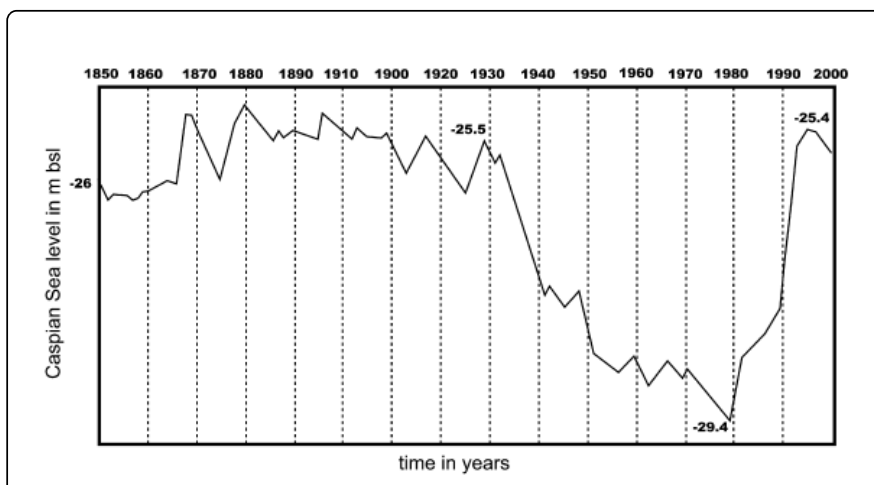

Figure 2: Caspian Sea curve since 1850 [10]. 
Citation: Emadodin S, Zahabnazouri S (2018) Marine Terraces as Geomorphic Evidence of Different Tectonic Regimes in Southeastern Part of The Caspian Sea in the Late Quaternary. J Coast Zone Manag 21: 462. doi:10.4172/2473-3350.1000462

Page 2 of 7

The Khazar fault, an active thrust fault in the northern part of the Alborz Range is the boundary between the Caspian plain and Alborz Mountain. Subsidence in the South Caspian [20] basin and uplift of the Alborz Mountain occurred along the Caspian fault [21]. Based on geological data, uplifting and subsidence occurred on the different parts of the Caspian coast with various rates [22,23]. This uplift/ subsidence affected the mouth of rivers which flow into the Caspian Sea [24]. Previous studies on the Caspian Coast focused on the impact of the present and past sea-level fluctuations on the coastal morphology and deposits [3,4,6-10,25-28]. In this study coastal uplift in the eastern and southern shores of the Caspian Sea in Iran is investigated. To carry out the research, dating of bivalve shells in marine terraces of the southeast coast of the Caspian Sea were used to determine the age of terraces and afterwards the exact height of sampling points were determined. Finally, the age and height of terraces in the eastern and southern part of the Caspian Sea were compared and the effect of tectonic on the terraces was investigated [29].

\section{Geographic setting}

The study area is located along Iranian coast of the Caspian Sea in Mazandaran and Golestan Provinces [30]. The area of investigation included Eastern area of Mazanderan province (Neka River) and Eastern part of Golestan Province (Gorgan River) (Figure 3). The eastern shores of Golestan Province have a semi-arid climate. The mean annual precipitation is $350 \mathrm{~mm}$; the average maximum temperature is $22.3^{\circ} \mathrm{C}$. Main channel slope of Gorgan River is $0.1 \%$. The Eastern Mazandaran shore, where Neka River flows, has a semihumid climate. The mean annual precipitation is $900 \mathrm{~mm} /$ years. Main channel slope of Neka River is $1.7 \%$.

Golestan coast is more sensitive to sea-level fluctuations due to its gentle slope and excellent preservation conditions. Gentle slope of this coast does not allow wave action on the shore. This provides desirable conditions for understanding the South Caspian coastal response to sea-level fluctuations.

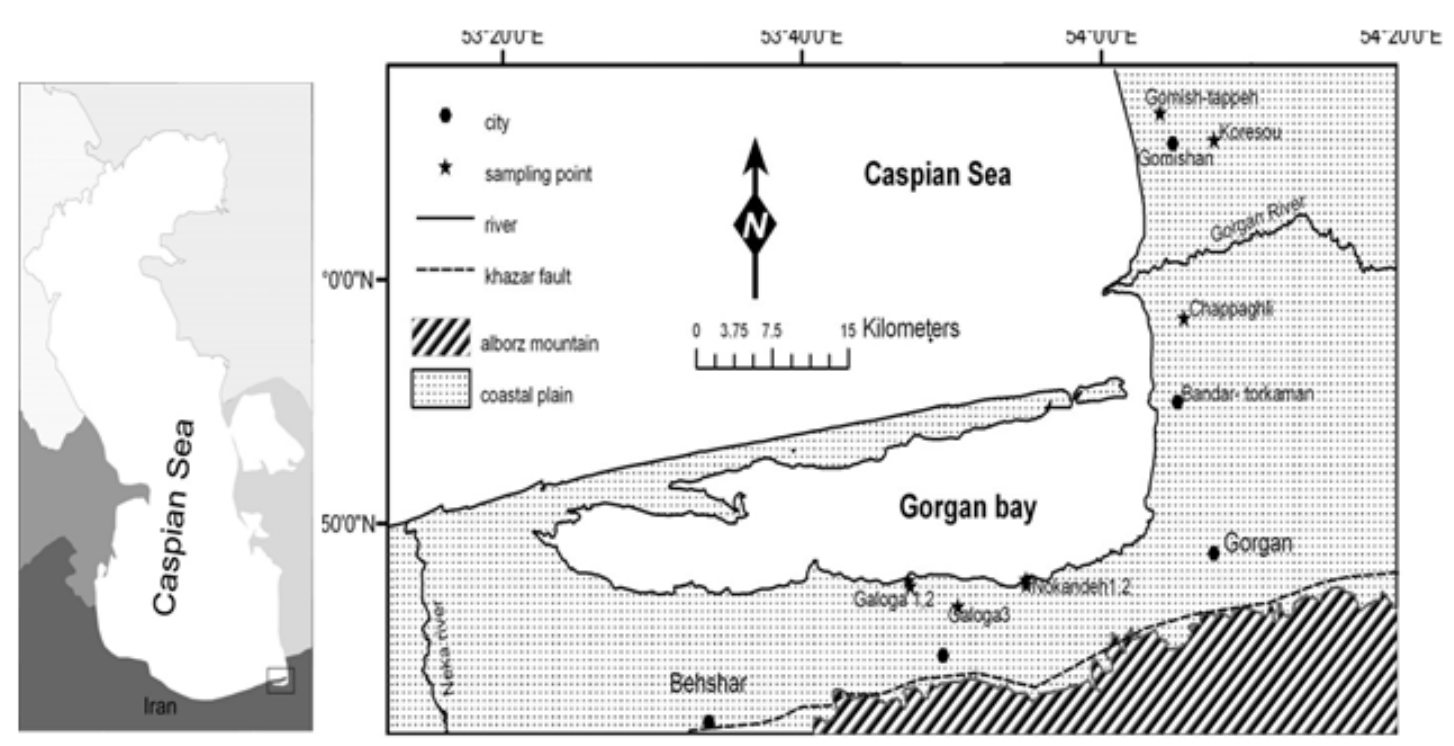

Figure 3: Location map of study area of the southeastern Caspian Sea.

\section{Materials and Methods}

In this study paleo-marine terraces around Neka River were identified and studied and then compared with the paleo terraces around Gorgan River. In Neka region, erosional factors, flooding and human activities resulted in concealing the marine terraces. As a result, the terraces located in the south of Gorgan Bay through which Neka River flowed to Gorgan bay in the late Holocene were considered [31]. Extensive field observations in the coastal area in the eastern Mazandaran (Neka River) and eastern Golestan were performed to discover suitable outcrops and coring sites to represent the Late Holocene records. In eastern Mazandaran, four outcrops and eastern Golestan, two outcrops and one coring site were found. Afterwards eight bivalve samples (Cerastoderma Glaucum) from old marine terraces were selected and sent to Shirakava Radiocarbon Laboratory (Japan) for radiocarbon dating to determine the absolute age of terraces $[32,33]$. Coordinates of the studied sites were determined using a DGPS device. The altitudes of the dated horizons were leveled through comparison with the nearest benchmark of the Iranian Cartographic Center (Bandar- Gaz and Chappaghli), which are based on the Persian Gulf mean water level. Two beach profiles were surveyed from Koresou and Galogah1 outcrops to shoreline using a Leica TCR- 407 Total Station. The results were used to draw the terraces profiles in the studied areas.

Remote sensing data (Aster and Landsat), old maps (1890) and field observations were used to show recent coastal evolution, as well as the impact of the last sea-level cycle between 1929 and 1995.

\section{Results and Discussion}

\section{Marine terraces}

Marine terraces are excellent morphological markers and are used world- wide to recognize past sea-level changes [34]. Marine terraces also are important markers for quantifying coastal uplift as well [35]. 
Citation: Emadodin S, Zahabnazouri S (2018) Marine Terraces as Geomorphic Evidence of Different Tectonic Regimes in Southeastern Part of The Caspian Sea in the Late Quaternary. J Coast Zone Manag 21: 462. doi:10.4172/2473-3350.1000462

Page 3 of 7

Coastal neotectonic investigations [36] are favored by the presence of marine terraces. These morphological features provide a reference and chronological data of the sea levels against which the progress of uplift and deformation can be traced. In coastal settings, uplifted coastal deposits and landforms (marine terraces) provide useful markers to calculate tectonic uplift rates [37-40]. In addition, sea level is important to study active tectonics because it is a unique horizontal datum - a widespread plane of equal elevation. Because coastal landforms are created at or near sea level, finding old coastal features some distance above the modern coastline could indicate tectonic deformation of the surface since those features formed. Consequently, some of the most useful landforms for studies of active tectonics are coastal terraces. These landforms are prominent along many coastlines and they can be useful tools for measuring rates and patterns of tectonic uplift. In the study area, 4 marine terraces in $-21 / 9,-23 / 31$, $-24 / 17$ and $-26(\mathrm{~m})$ levels in the east of Caspian Sea (Figure 4) and 4 marine terraces in the south of Caspian Sea in $-23 / 15,-21 / 89 .-22 / 30,-22 / 68$ and $-22 / 05(\mathrm{~m})$ (Figure 5) levels were detected using field observation and satellite images. Based on dating results, age of these terraces are $653 \pm 24,940 \pm 24,478 \pm 23$ and 32 years ago in the east of Caspian Sea and $461 \pm 22,496 \pm 22,541 \pm 23$, $594 \pm 22$ and $2438 \pm 24$ years ago in the south of Caspian Sea.
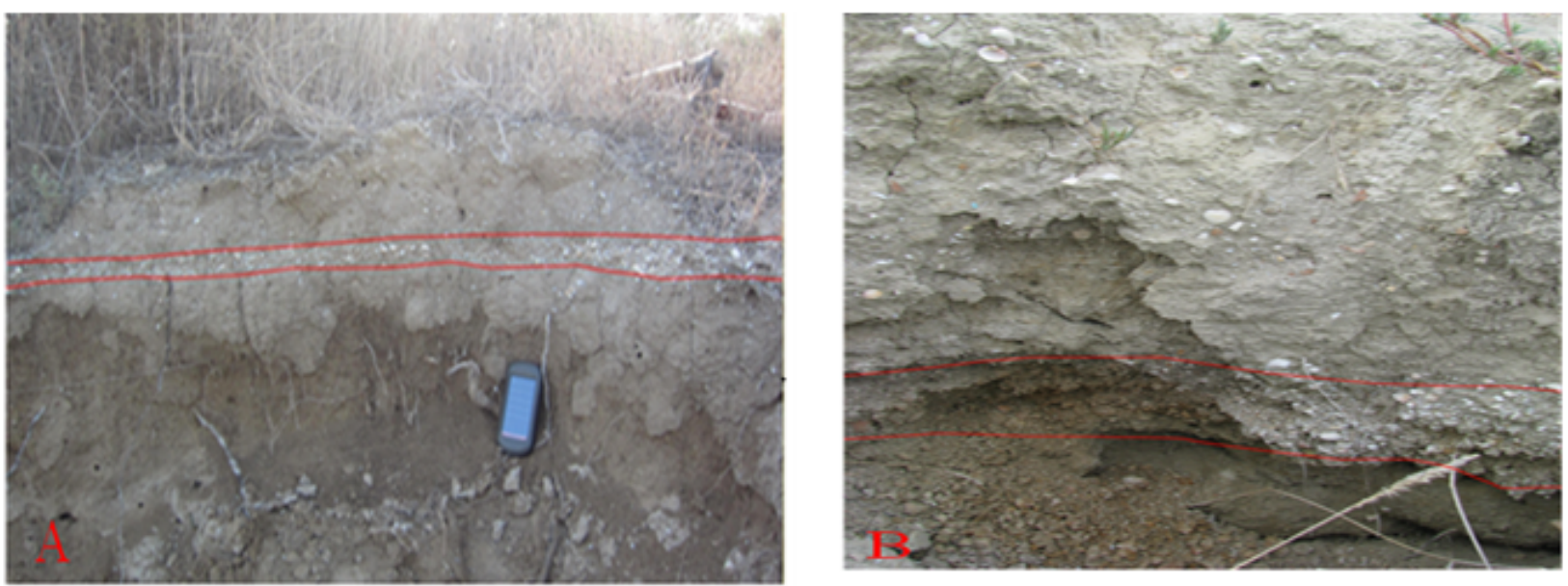

Figure 4: Marine terraces represented by shell beds in paleo-shore line, in Chapaghli (A) and Ghomishtappeh (B), in the east of Caspian Sea. 
Citation: Emadodin S, Zahabnazouri S (2018) Marine Terraces as Geomorphic Evidence of Different Tectonic Regimes in Southeastern Part of The Caspian Sea in the Late Quaternary. J Coast Zone Manag 21: 462. doi:10.4172/2473-3350.1000462

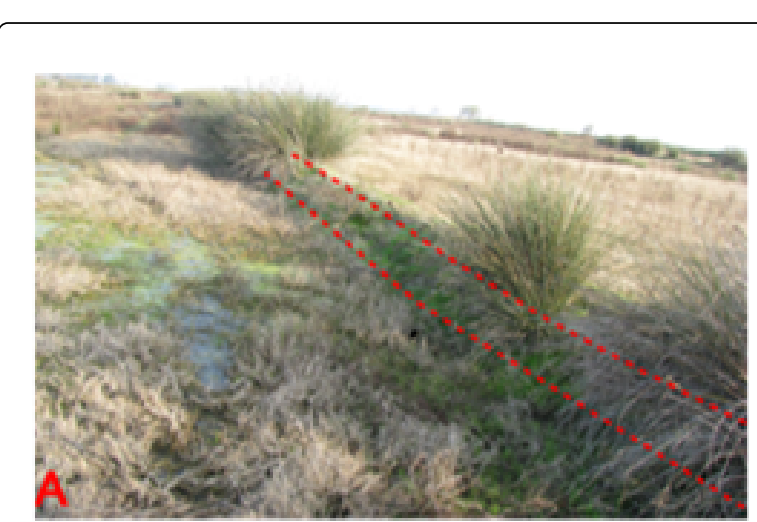

$461 \pm 22$
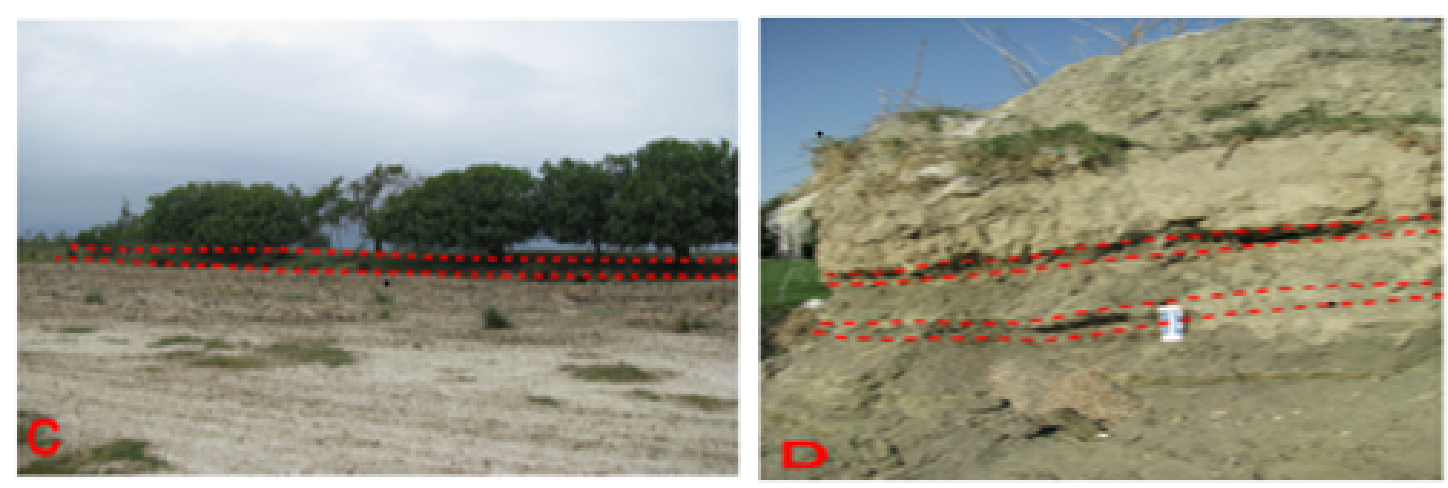

$5-41 \pm 23$

$59-4 \pm 22$

\section{$2438 \pm 24$}

|

Figure 5: Marine terraces identified in the field in A(Galogah1) B (Galoga 2), C (Galogah Gascompany D (near the river Nukandeh) in the south of Caspian Sea. The absolute dates are written below or beside the figurers.

\section{Results of age determination}

For radiometric dating of marine terraces, 8 Samples were selected carefully and only double- valve mollusks were considered for dating analysis, in order to avoid sampling reworked specimens that yield an overestimation of the actual age of the deposits $[18,41]$.

\begin{tabular}{|c|c|c|c|c|}
\hline Sample ID & Present Elevation & $\begin{array}{l}\text { Depth of sampling from earth } \\
\text { surface }(\mathrm{cm})\end{array}$ & Dated material & $14 \mathrm{c}$ age(BP) \\
\hline Gomishtappet terrace & -24.17 & -23 & Shell(bivalve) & $475 \pm 23$ \\
\hline Koresou terrace & -23.31 & -60 & Shell(bivalve) & $940 \pm 24$ \\
\hline Chappaghli terrace & -21.9 & -30 & Shell(bivalve) & $655 \pm 24$ \\
\hline Galloga 1 terrace & -23.15 & -23 & Shell(bivalve) & $461 \pm 22$ \\
\hline Galloga 2 terrace & -21.89 & -80 & Shell(bivalve) & $496 \pm 22$ \\
\hline Nokande 1 terrace & -22.30 & -95 & Shell(bivalve) & $541 \pm 23$ \\
\hline Nokande 2 terrace & -22.68 & -110 & Shell(bivalve) & $594 \pm 22$ \\
\hline Galoga 3 terrace & -22.05 & -30 & Shell(bivalve) & $2438 \pm 24$ \\
\hline
\end{tabular}

Table 1: 14C AMS dates of shell fragments. 
Galogah1 and Gomishtappeh terraces approximately have similar age. Galogah 1 terrace has an age of $461 \pm 22$ and Gomishtappeh has an age of $478 \pm 23$ years BP. Water level in Galogah 1 is-23/15 $\mathrm{m}$ and in Gomishtappeh is $-24 / 17 \mathrm{~m}$. According to their similar age Galogah 1 terrace is located about $1 / 02 \mathrm{~m}$ above Gomishtappeh terrace.

Galogah 2 and Chapoghli terraces have approximately the same height, while having different ages. Gallogah 2 terrace height is -21.90 $\mathrm{m}$ and Chappaghli height has a height of- $21 / 88 \mathrm{~m}$. Galoghah 2 terrace has an age of $496 \pm 22$ years and Chappaghli terrace has an age of 653 \pm 24 years. Gallogah 2 terrace is approximately younger than Chappaghliinage. If tectonic did not act, Gallohah 2 terrace should be located in a lower position (height) than Chappaghli, while it is located in a higher position. This can be related to tectonic influence in the region.

The distance from Chappaghli and Galogah 1 and 2 terraces to the coast is 9600 and $1250 \mathrm{~m}$ respectively. This shows that in the eastern part of the Caspian Sea due to the lower degree in slope, during transgression and regression the horizontal shifting of the shoreline was greater in comparison to the southern part. Besides, there is a height difference between terraces in the southern part. For example, in Nokandeh outcrop there are two terraces. Nokandeh 1 has an age of $541 \pm 23$ and Nokandeh 2 has an age of $594 \pm 22$ years BP. The height of Nokandeh1site is -22.30 and the height of Nokandeh 2 site is $-22.68 \mathrm{~m}$. this illustrates about $0.38 \mathrm{~m}$ difference in the height between two sites within 53 years' time. Galogah 1 terrace has an age of $461 \pm 22$ and
Galogah 2 terrace has an age of $496 \pm 22$ years BP. The height of Galogah 1 terrace is $-23 / 15 \mathrm{~m}$ and the height of Galogah 2 terrace is $-28 / 89 \mathrm{~m}$. There is about $200 \mathrm{~m}$ distance between Galogah 1 and 2 terraces and this shows that during 35 years a height difference of about $1 / 26$ m occurred.

\section{Measuring and comparing heights of marine terraces in the study area}

After dating the fossil samples from different terraces (Table 1), it was necessary to measure the exact position and elevation of the terrace sand draw topographic cross-section of them up to Caspian shore. These measurements were carried out to be used as geomorphic evidences for clarification of tectonic role in the study area. To carry out this, first by using a 2 -frequency GPS the coordination of each sampling point in marine terraces were determined. Afterwards the position of each profile line was measured from each sampling point up to the sea shore by using a total station device then by using an engineering leveling tool the leveling survey along the profile line was carried out. Comparison of the profiles represented the differences in the slope of the ground in two eastern and southern parts of the Caspian Sea so that in the eastern part the general slope in Koresou was $0.035 \%$ but in the southern part the slope was higher: in Galoogah 2 the slope was $0.6 \%$ and the slope between the first and second terraces in Galoogah represented a difference in elevation as much as 1/26 (Figure 6).

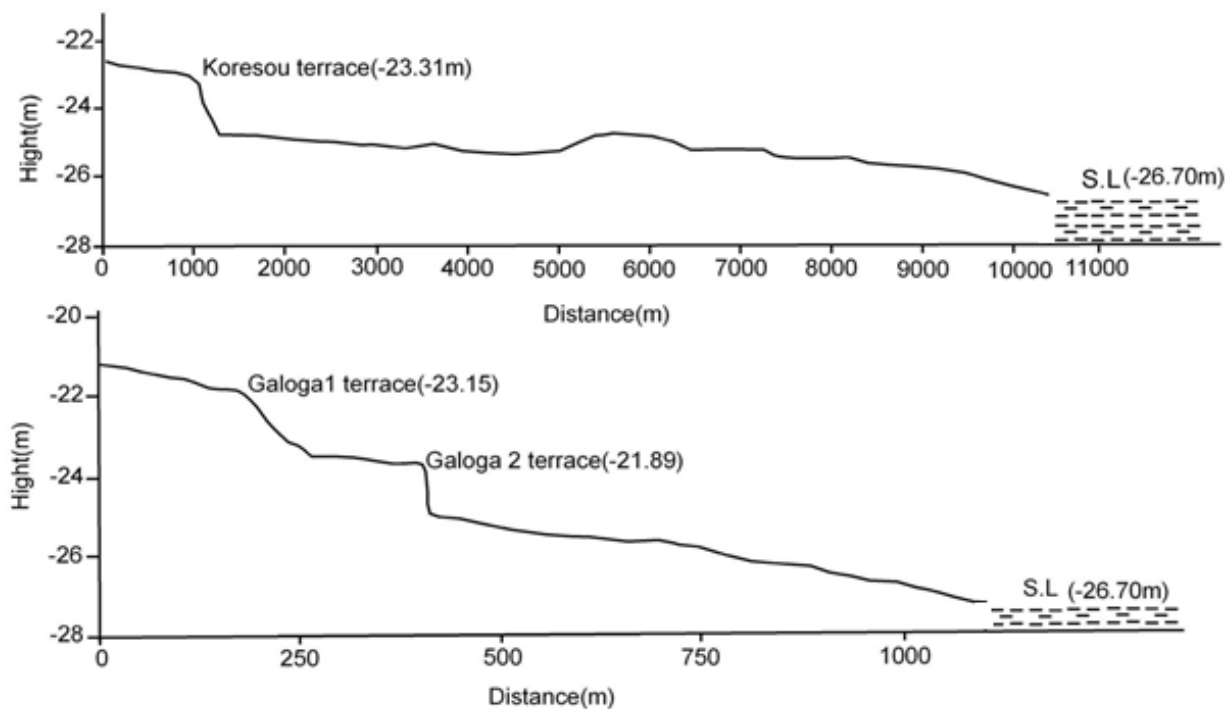

Figure 6: The topographic profile of the sampling points to the Caspian coast.

\section{Conclusion}

The studied area represents one of the best locations to show geomorphologic evidences of Caspian Sea level change in the late Quaternary. Although the area is vastly affected by human activities, the south eastern part of Caspian coastal area is still considered as an undisturbed area. The Gorgan and Neka rivers courses as our case study near their discharge point don't show similar conditions from river course down cutting and sequence of sedimentation point of view. Neka River cut its course more deeply near its discharge point. 
This was resulted from tectonic activity of the active faults in this region. To estimate the amount of coastal uplift and Neka River down cutting, the marine terraces were used as the geomorphologic indices to represent the role of tectonic activity in the study area. Illustrating the effects of tectonic activity and its rates was made possible via studying the evolution of these evidences. The dating results represent that different tectonic activity regimes caused down cutting of Neka River due to Alborz uplift. Results show that within the last 500 years due to Alborz uplift the terraces located in the southern part of the Caspian Sea uplifted 1/02 meters above the same age terraces in the eastern part of it.

\section{References}

1. Kaplin PA, Selivanov AO (1995) Recent coastal evolution of the Caspian Sea as a natural model for coastal response to the possible acceleration of global sea-level rise. Mar Geol 124: 171-17.

2. Jones RW, Simmons MD (1996) A review of the stratigraphy of eastern paratethys (Oligocene Holocene). Bulletin of the Natural History Museum, London (Geology) 52: 25-49.

3. Rychagov GI (1997) Holocene Oscillations of the Caspian Sea and forecasts based on paleogeographical reconstructions, Quaternary International 41-42: 167-172.

4. Mamedov AV (1997) The late Pleistocene-Holocene history of the Caspian Sea. Quaternary International 41-42: 161-166.

5. Overeem I, Kroonenberg SB, Veldkamp A, Groenesteijn K, Rusakov GV et al. (2003) Small-scale stratigraphy in a large ramp delta: recent and Holocene sedimentation in the Volga delta, Caspian Sea. Sediment Geology 159: 133- 157.

6. Hoogendoorn RM, Boels JF, Kroonenberg, SB, Simmons MD, Aliyeva E, et al. (2005) Development of the Kura delta, Azerbaijan; a record of Holocene Caspian Sea-level changes. Marine Geology 222-223: 359-380.

7. Kroonenberg SB, Rusakov GV, Svitoch AA (1997)The wandering of the Volga delta: response to rapid Caspian Sea-level changes. Sediment Geology 107: 189-209.

8. Kroonenberg SB, Badyukova EN, Storms JEA, Ignatov EI, Kasimov NS (2000) A full sealevel cycle in 65 years: barrier dynamics along Caspian shores. Sedimentary Geology 134: 257-274.

9. Kroonenberg SB, Abdurakhmanov GM, Badyukov EN, van der Borg K Kalashnikov A, et al. (2007) Solar-forced 2600 BP and Little Ice Age highstands of the Caspian Sea. Quaternary International (173-174): 137-143.

10. Kakroodi AA, Kroonenberg SB, Mohamah Khani H, Yamani M, Hgasem MR (2012) Rapid Holocene sea-level changes along the Iranian Caspian coast. Quaternary International 263: 93-103.

11. Tudryn A, Chalie F, Lavrushin YUA, Antipov MP, Spiridonova EA, et al (2013) Late Quaternary Caspian sea environment Lake Khazarian and Early Khalynian transgressions from the lower reaches of the Volga River. Quaternary International 292: 193-204.

12. Leory SAG, Lopez-Merina L, Tudryn A, Chalie F, Gasse F (2014) Late Pleistocene and Holocene palaeoenvironments in and around the middle Caspian basin as reconstructed from a deep-sea core. Quaternary Science Reviews 101: 91-110.

13. Rodionov S (1994) Global and Regional Climate Interaction: The Caspian Sea Experience. Kluwer Dordrecht p254.

14. Warrick RA (1993) Climate and sea level change a synthesis (In Warrick RA) Cambridge University Press, Cambridge, pp.3-21.

15. Renssen H, Lougheed BC, Aerts JCJH, Moel Hde, Ward PJ, et al. (2007) Simulating long-term Caspian sea level changes: the impact of Holocene and future climate conditions. Earth and Planetary Science Letters 261: 685-693.

16. Svitoch AA (2009) Khvalynian transgression of the Caspiab Sea was not a result of water overflow from the Siberian Proglaciallakes nor a prototype of the Noachian flood. Quaternary International197: 115-125.
17. Vdovykin GP (1990) Caspian Sea Level Variations in Relation to Neotectonic Movements. Dokl Akad Nauk SSSR 310: 673-675.

18. Shilo NA, Krivoshei MI (1989) Relationship between the Caspian Sea Level Fluctuations and Crustal Stresses. Vestn Akad Nauk SSSR 6: 83-90.

19. Federov PV (1995) Modern geology of the Caspian Sea, Russian Academy of Science Bulletin 65 : 622-625.

20. Rychagov GI (1993) The level of the Caspian Sea in historic times, Moscow University 5 : 42- 49.

21. Jackson J, Priestley K, Allen M, Berberian M (2002) Active tectonics of the south Caspian basin. Geophysical Journal International 148: 214-245.

22. Ghassemi MR (2005) Drainge evolution in response to fold growth in the hanging wall of the Khazar fault. north- eastern Alborz, Iran Basin research 17:425-436.

23. Brunet MF, Korotaev MV, Ershov AV, Nikishin AM (2003) The South Caspian Basin: a review of its evolution from subsidence modeling. Sedimentary Geology 156: 119-148.

24. Vernant Ph, Nilforoushan F, Chery J, Bayer R, Djamour Y, et al. (2004) Deciphering oblique shortening of central Alborz in Iran using geodetic data. Earth and Planetary Science Letters 223: 177-185.

25. Golonka J (2004) Plate tectonic evolution of the southern margin of Eurasia in the Mesozoic and Cenozoic. Tectonophysics, 381: 235-273.

26. Zenkovich VP (1957) Structure of the south-east coast of the Caspian Sea. USSR Academy of Sciences. Oceanographic commission works II: 4-11.

27. Voropaev GV, Krasnozhon GF, Lahijani H (1998) Caspian river deltas Caspian Bulletin $1: 23-27$.

28. Kazanci N, Gulbabazadeh T, Leroy SAG (2004) Sedimentary and environmental characteristics of the Gilan-Mazenderan plain northern Iran: influence of long-and short-term Caspian water level fluctuations on geomorphology. Marine Systems 46: 145-168.

29. Berbrian, M, Robert S (2001) Contribution of archaeological data to studies of earthquake history in the Iranian Plateau. journal of Structural Geology 23: 563-584.

30. Lahijani H, Rahimpour -Bonab H, Tavakoli V, Hosseindoost M (2009) Evidence for late Holocene highstands in Central Guilan-East Mazandaran, South Caspian coast. Quaternary International 197: 55-71.

31. Karpychev YA (1989) Changes in the Caspian Sea-level in the Holocene according to radiocarbon date. Water Resourses 1: 5-20.

32. Svitoch AA (2005) Choronology of the Holocene Caspian sea-level oscillation, International Conference on Rapid Sea-Level Change:A Caspian Perspective, University of Guilan,Rasht,Iran,p97.

33. Stuiver M, Polach HA (1977) Discussion: Reporting of $14 \mathrm{C}$ data Radiocarbon 19: 355-363.

34. Gaki-Papanastassiou k, Karymbalis E, Papanastassious D, Maroukian H (2009) Quaternary marine terraces as indicators of neotectonic activity of the Ierapetra normal fault SE Crete (Greece). Geomorphology 104: 38-46.

35. Andean coastal uplift and active tectonics in southern Peru : Be-10 surface exposure dating of differentially uplifted marine terrace sequences (San Juan de Marcona, similar to 15.4 degrees S) Geomorphology 128, pp: 178-190.

36. Gallagher R (2010) Observations of terracing and strandlines in Azerbaijan in association with mud volcanoes as indicators of past fresh and sea water inundations. International conference Moscow.

37. Chappell J (1974) Geology of coral terraces, Huon Peninsula, New Guinea, A study of quaternary tectonic movements and sea-level changes. Geological Society of America Bulletin 85: 553-570.

38. Lajoie KR (1986) Coastal tectonics Active tectonics. National Academic Press. Washington DC, pp95-124.

39. Merritts DJ, Bull WB (1989) Interpreting Quaternary uplift rates at the Mendocino triple junction, $\mathrm{N}$ northern California from uplifted marine terraces. Geology 17: 1020-1024.

40. Berryman K, Hull A, Miyauchi T (1988) Age and height distribution of Holocene transgressive deposits in eastern North Island, New Zealand. 68: 135-151.

41. Svitoch AA, Badyukova EN, Kroonenberg SB, Parunin OB, Vonhof HV (2006) Radiocarbon dating of molluskshells from marine deposits from 
Citation: Emadodin S, Zahabnazouri S (2018) Marine Terraces as Geomorphic Evidence of Different Tectonic Regimes in Southeastern Part of The Caspian Sea in the Late Quaternary. J Coast Zone Manag 21: 462. doi:10.4172/2473-3350.1000462

the Caspian shore in Dagestan. Bullentin of Moscow State University,

Russia 53: 13-21 